\title{
The development of a mobile psychiatric unit in a rural area of Greece: preliminary results
}

\author{
Vassiliki Mouka*1,2, Vaios Peritogiannis ${ }^{1,2}$, Mariana Lekka ${ }^{1}$, Menti Nepheli ${ }^{1}$, \\ Mavreas Venetsanos ${ }^{1,2}$ and Thomas Hyphantis ${ }^{1,2}$
}

\author{
Address: ${ }^{1}$ Mobile Psychiatric Unit of the Prefectures of Ioannina and Thesprotia, Greece and ${ }^{2}$ Department of Psychiatry, Medical School, University \\ of Ioannina, Ioannina, Greece \\ * Corresponding author
}

from International Society on Brain and Behaviour: 3rd International Congress on Brain and Behaviour

Thessaloniki, Greece. 28 November - 2 December 2007

Published: 17 April 2008

Annals of General Psychiatry 2008, 7(Suppl I):S280 doi:I0.I I86/I744-859X-7-SI-S280

This abstract is available from: http://www.annals-general-psychiatry.com/content/7/SI/S280

(c) 2008 Mouka et al.; licensee BioMed Central Ltd.

\section{Background}

The most radical form of community treatment involves attempts to develop a community-treatment alternative to mental hospital. One interesting and effective community oriented model is the development of services such as Mobile Psychiatric Units in rural areas, which contributes considerably to the establishment of an organized net of psychiatric care that covers the broad needs of the remote areas. This study presents the development of the recently established Mobile Psychiatric Unit of the prefectures of Ioannina and Thesprotia (M.P.U. I-T), Greece, as well as the results of its operation during the first six-month period of its establishment.

\section{Materials and methods}

The M.P.U. is a specialized multidisciplinary team which provides psychiatric services and promotes mental health in the rural areas of the prefectures of Ioannina and Thesprotia, for a population of about 100.000 people. The M.P.U. visits 8 Health Centers of the Primary Health Care once a week, and has the potential to examine patients at home, while a close cooperation with almost all Home Care Programs within the catchment area has been also established. Patients were examined by the MPU staff and medical data were also collected in order to better identify the needs of the patients living in these remote areas.

\section{Results}

344 therapeutic actions have been recorded within this first six months period of the MPU development. 106 $(30.8 \%)$ were visits at the patients' homes. During this period, the number of the patients was gradually increased, reaching currently a total of 132 patients, whereas 42 patients are permanently followed-up by the MPU. 19 patients had psychotic disorders and 17 had affective disorders. Emphasis is also given in supporting the patients to the management of their practical needs and the attendance of their compliance. Since one of the main goals is the undertaking of activities that promote mental health and implement educational programs in the community, 58 promotion activities, 55 meetings with members of Primary care services, 9 meetings with members of the local authorities, and 18 meetings with other corporations, such as rehabilitation centers, social support organizations, hospital administrations and the church have been developed within the same period.

\section{Conclusions}

It has been mentioned that the basic principles in managing a psychotic patient should be that he gets what he needs, when he needs it and where best possible. Although the present findings are only preliminary, they provide initial evidence about the increased needs of the rural areas for the development of community-based mental health services and that a community-oriented 
programme based on Mobile Psychiatric Units offers quite satisfactory results in this direction.

Publish with Bio Med Central and every scientist can read your work free of charge

"BioMed Central will be the most significant development for disseminating the results of biomedical research in our lifetime. " Sir Paul Nurse, Cancer Research UK

Your research papers will be:

- available free of charge to the entire biomedical community

- peer reviewed and published immediately upon acceptance

- cited in PubMed and archived on PubMed Central

- yours - you keep the copyright 